\title{
Production and Partial Characterization of Lipase from Pseudomonas putida
}

\author{
Huda Fatima*, Natasha Khan, Asad Ur Rehman and Zahid Hussain
}

GC University, Katchery Road, Lahore, Pakistan

"Corresponding author: Huda Fatima, GC University, 3, Hill Crest, Swillington, Leeds. LS268DL, Lahore, Pakistan, Tel: +44 7463 390755; E-mail:

hudafatima160@gmail.com

Rec date: May 01, 2014, Acc date: Nov 05, 2014, Pub date: Nov 12, 2014

Copyright: (c) 2014 Fatima $\mathrm{H}$, et al. This is an open-access article distributed under the terms of the Creative Commons Attribution License, which permits unrestricted use, distribution, and reproduction in any medium, provided the original author and source are credited.

\begin{abstract}
The production of lipase from Pseudomonas putida 922 was optimized by modifying various physical parameters such as carbon source, nitrogen source, $\mathrm{pH}$, salt concentration and biochemical parameters of the production medium such as temperature and incubation time of the growth medium. Oil cakes were also used as carbon source to check for an increased production of the enzyme. The bacterium was found to have a maximal growth at $\mathrm{pH} 10$ with the enzyme production being highest $(24 \mathrm{U} / \mathrm{ml})$ after 48 hours at $30^{\circ} \mathrm{C}$ and $\mathrm{pH} 10$. The optimum composition of the medium was mustard oil cake as carbon source, yeast extract or peptone as nitrogen source and $1 \%$ sodium chloride concentration. Partial characterization of the enzyme was carried out where the optimum working $\mathrm{pH}$ and temperature was found to be 10 and $40^{\circ} \mathrm{C}$, respectively. Enzyme stability was found to lie in the $\mathrm{pH}$ and temperature ranges of $5-11$ and $30-40^{\circ} \mathrm{C}$, respectively. Partial purification of the enzyme was carried out at $80 \%$ ammonium sulphate saturation. Molecular mass of lipase was determined by SDS PAGE and found to be $45 \mathrm{kDa}$.
\end{abstract}

Keywords: Lipase; Pseudomonas putida; Optimization; Oil cakes; Characterization

\section{Introduction}

Lipases (triacylglycerol hydrolases) are a unique type of esterases that belong to the class 3 of enzymes and due to their specificity for hydrolyzing carboxylic acid ester bonds they have been assigned the EC number 3.1.1.3. The biological role of lipases is to carry out the hydrolysis of lipids such as triacylglycerols resulting in the production of free fatty acids along with diacylglycerols, mono-acyl glycerols or glycerol [1].

Lipases are an important class of enzymes that help microorganisms to derive energy from triacylglycerols. Lipases can be extracellular or intracellular in nature. This nature varies from organism to organism, however, majority of the bacteria have been found to secrete extracellular lipases [2].

Lipases are found abundantly in nature and have been found to be naturally synthesized by some plants such as Hibiscus cannabinus, animals such as some fish and insects, fungi such as Aspergillus $s p$. and bacteria such as that produced by Acinetobacter $s p$., Bacillus $s p$. [3] and Pseudomonas sp. [4].

However, lipases from microbial sources are commercially more significant since they have a lower cost of production, higher stability and a higher availability than other sources [5].

Bacterial lipases have been found to be influenced by physiochemical and nutritional factors such as temperature, $\mathrm{pH}$, nitrogen and carbon sources, presence of inorganic salts, lipids and usage of agitation [6]. The major content of lipase production media is the carbon source that also acts as an inducer for lipase production [7] whereas nitrogen sources and other components of the media help in regulation of the growth of the producer organism and therefore the fermentation process [8]. Microbial lipase production is usually carried out using submerged fermentation technique [9], however solid state fermentation methods have also been found to be beneficial [10]. Lipid carbon sources have been found to be generally important for obtaining a high lipolytic enzyme yield although a few researchers have obtained substantial lipase yields without using fats or oils [4].

Lipase is one of the versatile enzymes that can be used in a number of industries such as the food industry [11]. It is also used as a biosensor for bioremediation purposes [12]. Lipase is also an effective part of detergents used in industrial and domestic laundry and dishwashing [13] while also being used in the paper industry [14].

As there is versatility in the lipase enzyme, and since the lipase from Pseudomonas putida has not been previously been worked upon at the production level. Therefore, the results of the present investigation will provide an insight into improving the production of lipase by aiding the development of a feasible medium and characterization of lipase.

\section{Materials and Methods}

\section{Chemicals}

All chemicals were of analytical grade and procured from Sigma chemicals (USA), Fisher Scientific (UK), Merck (Germany) and Acros Organics (Belgium).

\section{Microorganism and culture maintenance}

Pseudomonas putida 922 was obtained from the culture bank of IMBT, TUG, Austria and was refreshed in Lauria Bertani (LB) agar slants that were kept at $30^{\circ} \mathrm{C}$ for 48 hours. The slants were then placed at $4^{\circ} \mathrm{C}$ in a cool lab (write maker and model). The master culture was maintained in glycerol stocks at $-80^{\circ} \mathrm{C}$. 
Page 2 of 7

\section{Preparation of inoculum}

Bacterial slants that were 48 hours old were used as inoculum where loopful of bacteria were aseptically suspended in the sterilized fermentation medium.

\section{Fermentation technique}

The bacterium was cultured using submerged fermentation and grown in sterilized medium containing $5 \mathrm{~g}$ of wheat bran dissolved in $50 \mathrm{ml}$ of freshly prepared minimal medium containing $\mathrm{Na}_{2} \mathrm{HPO}_{4} .2 \mathrm{H}_{2} \mathrm{O}(6 \mathrm{~g} / \mathrm{L}), \mathrm{NaCl}(5 \mathrm{~g} / \mathrm{L}), \mathrm{NH}_{4} \mathrm{Cl}(2 \mathrm{~g} / \mathrm{L}), \mathrm{MgSO}_{4} .7 \mathrm{H}_{2} \mathrm{O}$ $(0.1 \mathrm{~g} / \mathrm{L})$ and $\mathrm{KH}_{2} \mathrm{PO}_{4}(3 \mathrm{~g} / \mathrm{L})$ and incubated at $37^{\circ} \mathrm{C}$ at $200 \mathrm{rpm}$ for 48 hours in a shaking incubator.

\section{Analytical methods}

Enzyme extraction: After completion of incubation time, $50 \mathrm{ml}$ of $0.1 \mathrm{M}$ phosphate buffer ( $\mathrm{pH} 8)$ was added to the growth medium and incubated for another hour. Enzyme extraction was carried out by centrifugation of the growth medium at $5000 \mathrm{rpm}$ for 5 minutes after which the supernatant was harvested and used for lipase estimation.

Enzyme assay: Enzyme Assay was carried out using titration method that has been previously used by Venkateshwarlu and Reddy. The reaction mixture consisted of $0.5 \mathrm{ml}$ of $0.1 \mathrm{M}$ phosphate buffer, $0.5 \mathrm{ml}$ of enzyme extract and $1 \mathrm{ml}$ of substrate $(10 \% \mathrm{v} / \mathrm{v}$ olive oil emulsified with $10 \% \mathrm{w} / \mathrm{v}$ gum acacia in $0.1 \mathrm{Ml}$ phosphate buffer, $\mathrm{pH} 8$ ). The experimental tube was incubated for 10 minutes at $30^{\circ} \mathrm{C}$ whereas no incubation time was provided for the control tube. Inhibition of the enzyme was carried out by alcohol: acetone in 1:1 ratio. Using few drops of phenolphthalein indicator, titration was carried out against $0.1 \mathrm{~N}$ sodium hydroxide until pink color appeared.

The enzyme was estimated by the following formula;

Enzyme Units $(\mathrm{U} / \mathrm{ml} / \mathrm{min})=\Delta \mathrm{V}^{\star} \mathrm{N}^{\star} 1000^{\star}$ Dilution factor

$$
\text { Vsample }{ }^{\star} \text { Tmin }
$$

Where; $\Delta \mathrm{V}$ is $(\mathrm{V} 2-\mathrm{V} 1)$ or the volume of $\mathrm{NaOH}$ used for experimental - the volume of $\mathrm{NaOH}$ used for the control.

$\mathrm{N}$ is the normality of $\mathrm{NaOH}$ used for titration.

Dilution factor is obtained due to the usage of extraction buffer for extraction

$\mathrm{V}$ (sample) is the amount of enzyme extract taken for the reaction mixture

$\mathrm{T}(\mathrm{min})$ is the time of incubation in minutes.

A unit (U) of enzyme is taken as the amount of enzyme (lipase) that releases $1 \mu \mathrm{mol}$ of free fatty acids per minute under specific conditions of assay.

Protein estimation: Protein estimation was carried out using the Bradford method. Absorbance of enzyme extract was used to calculate the amount of protein present in the enzyme extract.

The specific activity of the enzyme was calculated using the following formula

$$
\begin{gathered}
\text { Specific activity }(\mathrm{U} / \mathrm{mg} \text { of protein })=\text { Enzyme activity }(\mathrm{U}) \\
\text { Protein content }(\mathrm{mg})
\end{gathered}
$$

\section{Optimization of parameters for enhanced lipase production}

The optimization was carried out by using $5 \mathrm{~g}$ of wheat bran as a carbon source in the medium employed for the optimization of temperature, $\mathrm{pH}$, incubation time, salt concentration and nitrogen sources. Olive oil $(1 \%(\mathrm{v} / \mathrm{v}))$ was also used as an inducer for enhanced lipase production.

Optimization of $\mathrm{pH}$ for microbial growth: Microbial growth was optimized by inoculating the bacteria in an autoclaved medium that had $\mathrm{pH}$ varying from 5.0-11.0 by dissolving components of the minimal medium in the buffer of desired $\mathrm{pH}$.

Optimization of temperature: Temperature optimization was carried out by growing the bacterium at temperatures $30,35,37$ and $40^{\circ} \mathrm{C}$ in a shaking incubator at $200 \mathrm{rpm}$.

Optimization of incubation time: Incubation time was optimized by incubating the bacterium in wheat bran containing growth medium for $24,48,72$ and 96 hours.

Optimization of carbon sources: Carbon sources were optimized by using oil cakes and carbohydrates in place of wheat bran. The oil cakes included mustard oil cake, almond oil cake, canola oil cake and coconut oil cake whereas the carbohydrates used included glucose, sucrose, fructose and maltose as $10 \% \mathrm{w} / \mathrm{v}$ in minimal medium.

Optimization of nitrogen sources: Nitrogen sources where optimized by replacing ammonium chloride with ammonium sulphate, yeast extract, malt extract, beef extract and peptone as 0.1 $\mathrm{g} / \mathrm{L}$.

Optimization of salt concentration: Different concentrations of sodium chloride such as $0.1,0.5,1.0$ and 1.5 were used for identifying concentration at which high lipase production could be achieved, where $1 \%$ is the concentration present in the minimal medium used in all experiments, i.e. $5 \mathrm{~g} / \mathrm{L}$.

\section{Production of lipase using optimized medium}

The parameters used above that gave maximum lipase production were then all used together in order to provide the necessary conditions for maximal lipase production after which the enzyme was harvested and then assayed.

\section{Partial characterization of lipase}

Enzyme characterization was also carried out by determining its activity at various temperatures where the $\mathrm{pH}$ of the buffer remained constant, and at various $\mathrm{pH}$ where the temperature was kept constant. Lipase temperature and $\mathrm{pH}$ stability was also evaluated by keeping the enzyme for $1 \mathrm{hr}$ at different temperatures and $\mathrm{pH}$, after which enzyme estimation was carried out.

\section{Partial purification of lipase}

Ammonium sulphate precipitation was used in order to partially purify crude lipase so that the molecular weight of the enzyme could be determined. Solid ammonium sulphate with varying saturations $(30,40,50,60,70$ and $80 \%)$ was added slowly to the crude enzyme with constant stirring on a magnetic plate at $4^{\circ} \mathrm{C}$ and kept overnight. After that, sample was centrifuged at $12,000 \mathrm{rpm}$ for 15 minutes. Supernatant and pellets were assayed for lipase activity. 
Citation: Fatima H, Khan N, Rehman AU, Hussain Z (2014) Production and Partial Characterization of Lipase from Pseudomonas putida.

\section{Determination of molecular weight of lipase}

Molecular weight of the enzyme was determined by SDS-PAGE.

\section{Results and Discussion}

\section{Effect of pH on microbial growth}

The bacterial growth was determined in the medium of different $\mathrm{pH}$ ranging from 5.0 to 11.0. The growth of bacteria was determined by determining absorbance at Spectrophotometer at $600 \mathrm{~nm}$. Maximum absorbance obtained was 18.506 at a $\mathrm{pH}$ of 10 while minimum absorbance was obtained at $\mathrm{pH} 6.0$ (Figure 1).

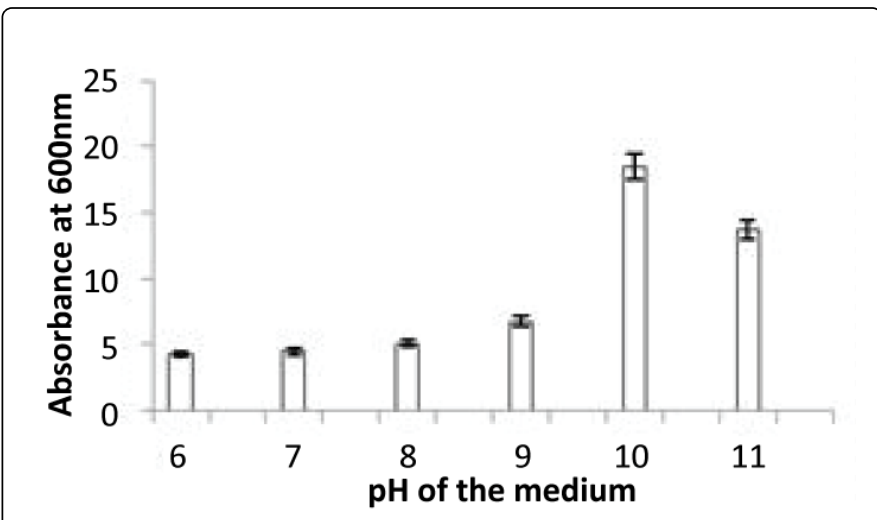

Figure 1: Effect of $\mathrm{pH}$ of medium on microbial growth.

\section{Effect of temperature on Lipase production}

The temperatures used for studying the effect of temperature on lipase production included $25,30,35,37$, and $40^{\circ} \mathrm{C}$. Lipase assay was carried out that revealed that the maximum production of lipase occurred at a temperature of $30^{\circ} \mathrm{C}$ and gave $24 \mathrm{U} / \mathrm{mL}$ (Figure 2).

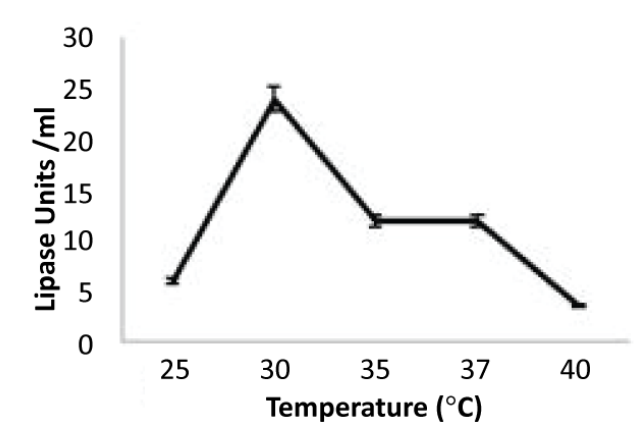

Figure 2: Effect of incubation time on lipase production.

Numerous incubation periods were studied such that the production medium was incubated for 24, 48, 72 and 96 hours and then lipase assay was carried out The maximum production of lipase occurred at 48 hours and gave $24 \mathrm{U} / \mathrm{mL}$ while minimum lipase production occurred at 72 and 96 hours with $6 \mathrm{U} / \mathrm{mL}$ (Figure 3).

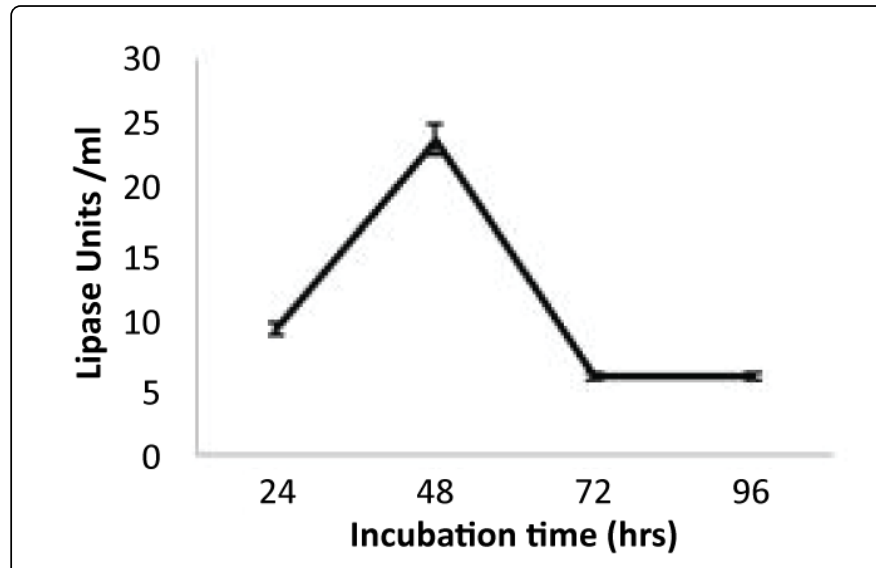

Figure 3: Effect of incubation time on lipase production.

\section{Effect of carbon source}

Numerous carbon sources such as oil cakes and carbohydrates were used for identifying the most suitable substrate for lipase production. Amongst the oil cakes mustard oil cake gave maximum lipase production $(60.5 \mathrm{U} / \mathrm{mL})$ while almond oil cake gave minimum lipase production $(5.5 \mathrm{U} / \mathrm{mL})$ (Figure 4). From among the carbohydrates the highest enzyme production was obtained by glucose and fructose (9.6 $\mathrm{U} / \mathrm{mL}$ each) with maltose giving no enzyme production (Figure 5).

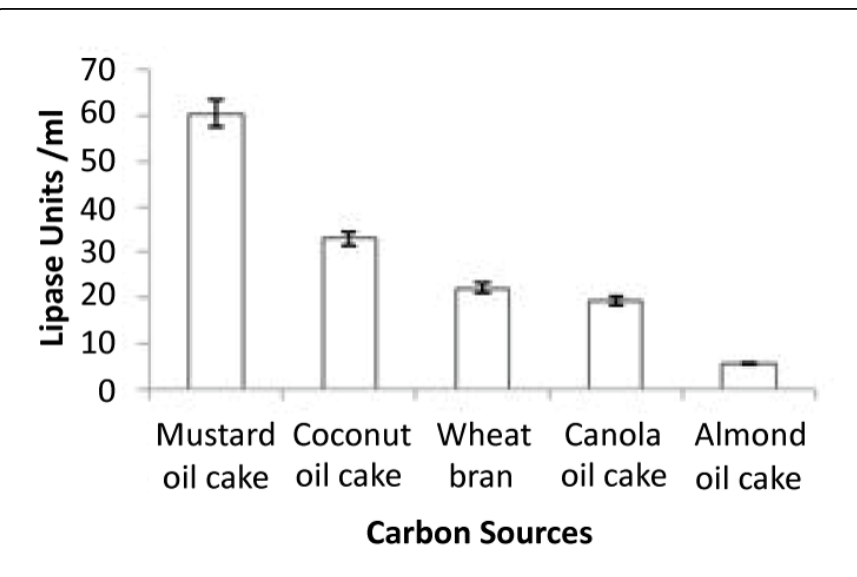

Figure 4: Effect of oil cakes as carbon source on lipase production. 
Citation: Fatima H, Khan N, Rehman AU, Hussain Z (2014) Production and Partial Characterization of Lipase from Pseudomonas putida.

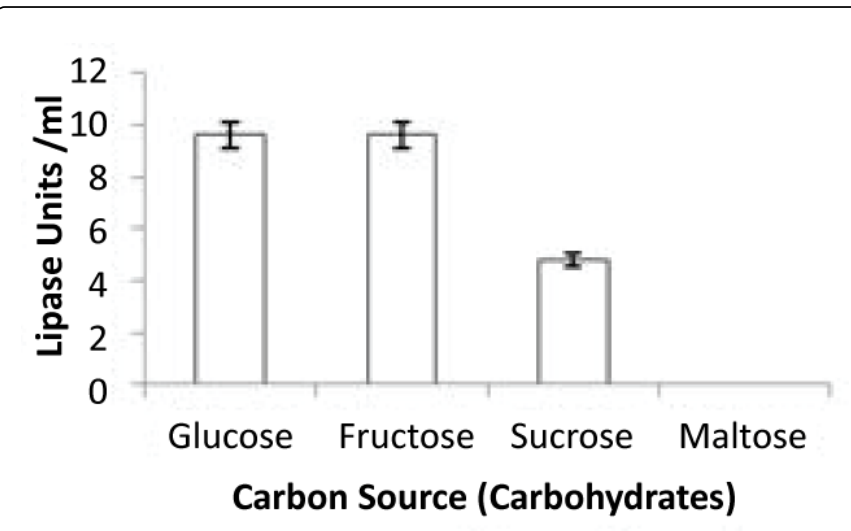

Figure 5: Effect of carbohydrates as carbon source on lipase production.

\section{Effect of nitrogen sources}

From amongst the nitrogen sources used, highest production of lipase was obtained by using Peptone and Yeast Extract, each of which gave $48 \mathrm{U} / \mathrm{mL}$. Lowest amount of lipase was produced by Ammonium Sulphate which gave $6 \mathrm{U} / \mathrm{mL}$ (Figure 6).

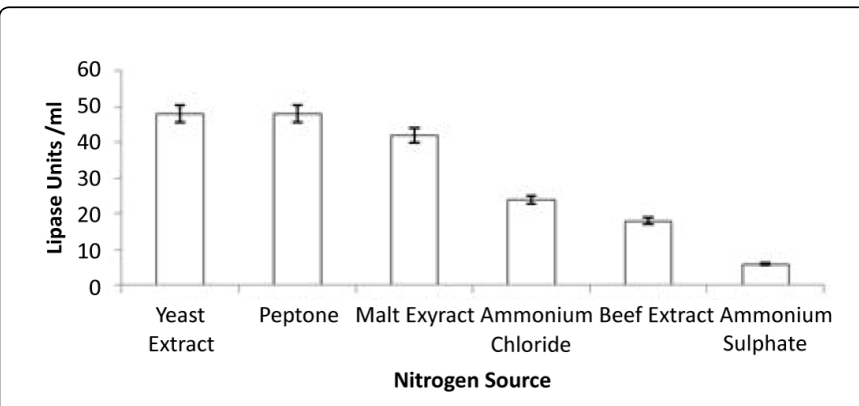

Figure 6: Effect of nitrogen source on lipase production.

\section{Effect of salt concentration}

Sodium chloride was used whose concentration was changed in the production medium where $1.0 \%$ is the salt concentration used in the minimal medium. Highest enzyme units were obtained when $1.0 \%$ of Sodium chloride was used $(24 \mathrm{U} / \mathrm{mL})$ while lowest enzyme units were obtained when $0.10 \%$ of salt concentration was used $(6 \mathrm{U} / \mathrm{mL}$ ) (Figure 7).

\section{Production of lipase using optimized medium}

Lipase production was enhanced by using optimized conditions and substances such as carbon and nitrogen sources that were meant to allow maximum growth of microorganism and lipase production as well. The results showed that the optimized medium produced 26 $\mathrm{U} / \mathrm{mL}$ with a specific activity of $119.54 \mathrm{U} / \mathrm{mg}$ of protein (Figure 8 ).

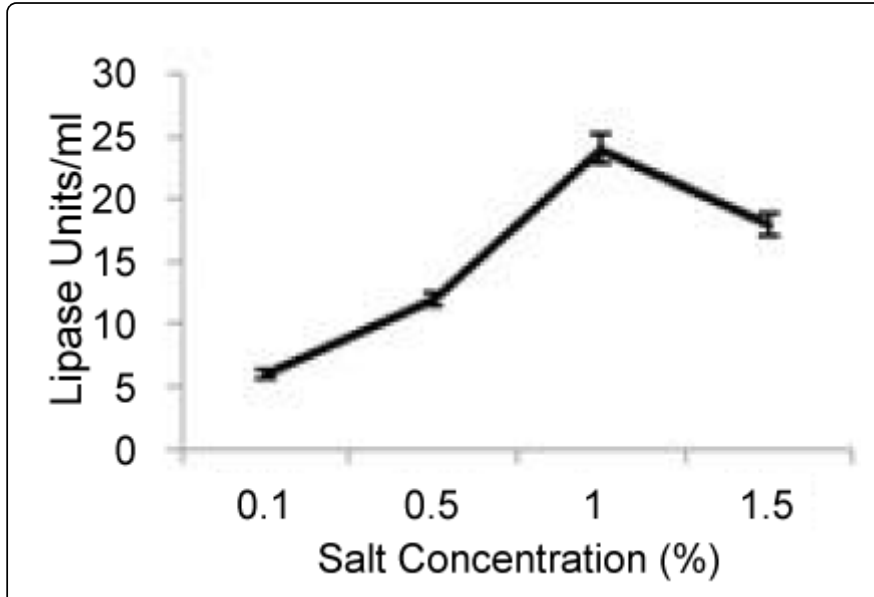

Figure 7: Effect of salt concentration on lipase production.

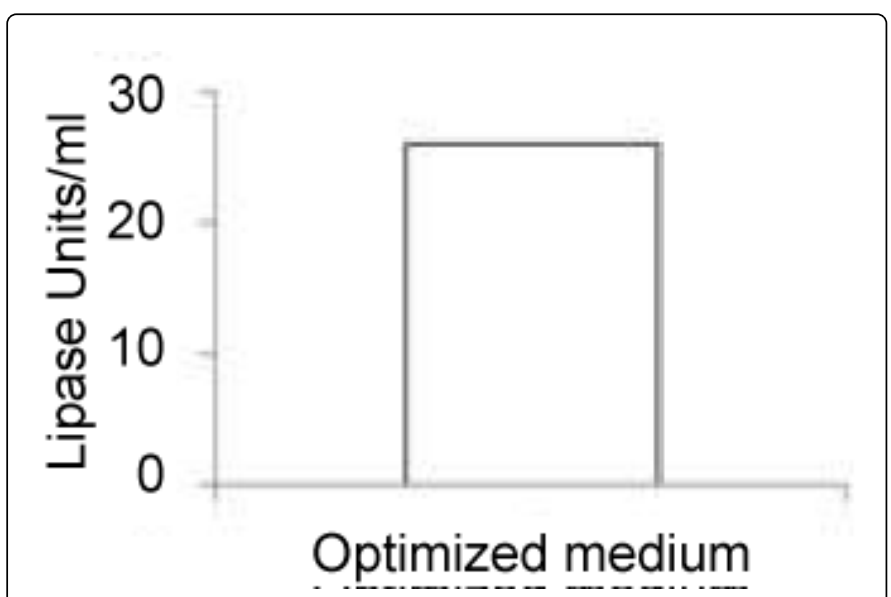

Figure 8: Production of lipase on optimization medium.

\section{Partial characterization of lipase}

Enzyme characterization was carried out by using the enzyme extract from the optimized medium and varying conditions in order to identify the optimum temperature (Figure 9) and $\mathrm{pH}$ (Figure 10) for enzyme activity along with the enzyme's stability at different temperature (Figure 11) and $\mathrm{pH}$ (Figure 12).

The optimum working temperature of the enzyme was found to be at $40^{\circ} \mathrm{C}(56.88 \mathrm{U} / \mathrm{mL})$ while the enzyme activity was found to decrease below and above $40^{\circ} \mathrm{C}$ where lipase may inactivate or achieve lower activity, respectively. The optimum working $\mathrm{pH}$ of the enzyme was found to be at $\mathrm{pH} 10(26 \mathrm{U} / \mathrm{mL})$ implying that the enzyme had the ability to work at fairly high alkaline conditions. 
Citation: Fatima H, Khan N, Rehman AU, Hussain Z (2014) Production and Partial Characterization of Lipase from Pseudomonas putida.

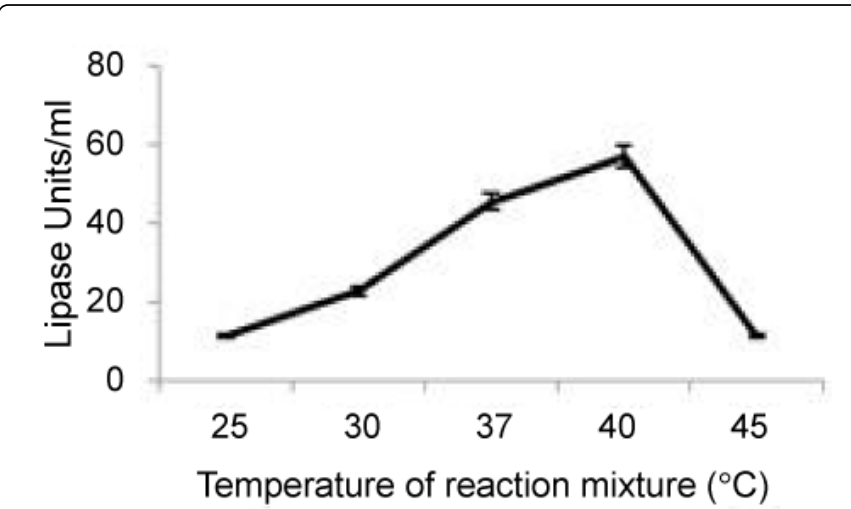

Figure 9: Determination of optimal temperature for lipase activity at $\mathrm{pH}$ 8.0.

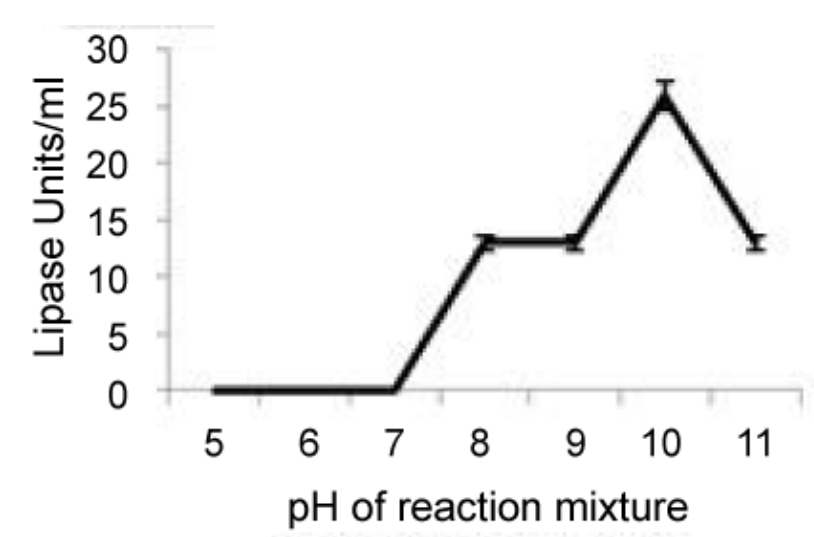

Figure 10: Determination of optimum $\mathrm{pH}$ for lipase activity at $30^{\circ} \mathrm{C}$

Thermostability of the enzyme was also assessed using different temperatures where the enzyme was found to be stable between 30 and $45^{\circ} \mathrm{C}$ whereas above and below this range the enzyme was unstable. Enzyme stability was also determined at different $\mathrm{pH}$ where the enzyme was found to be stable from $\mathrm{pH} 5$ to 10 .

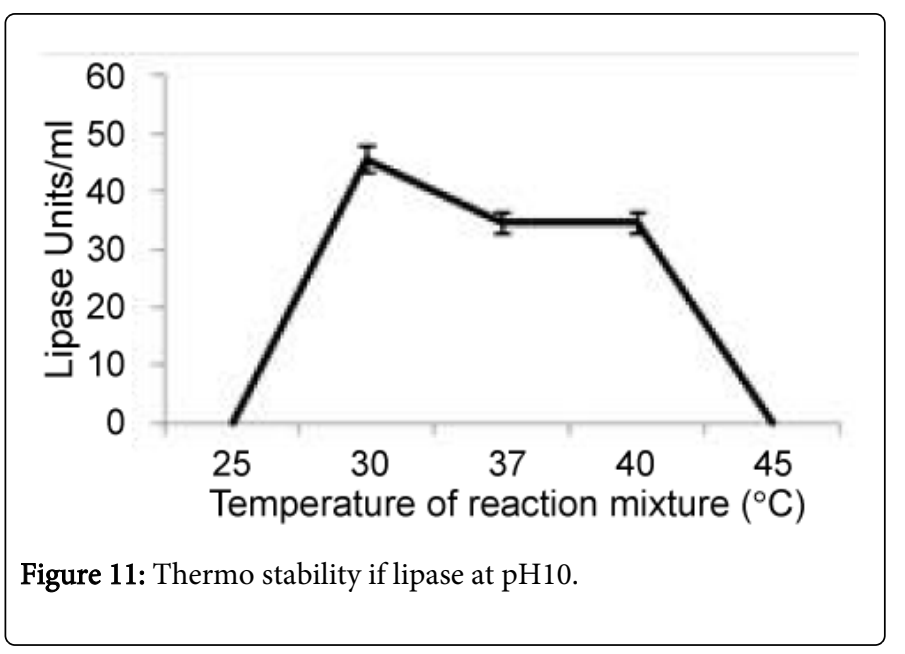

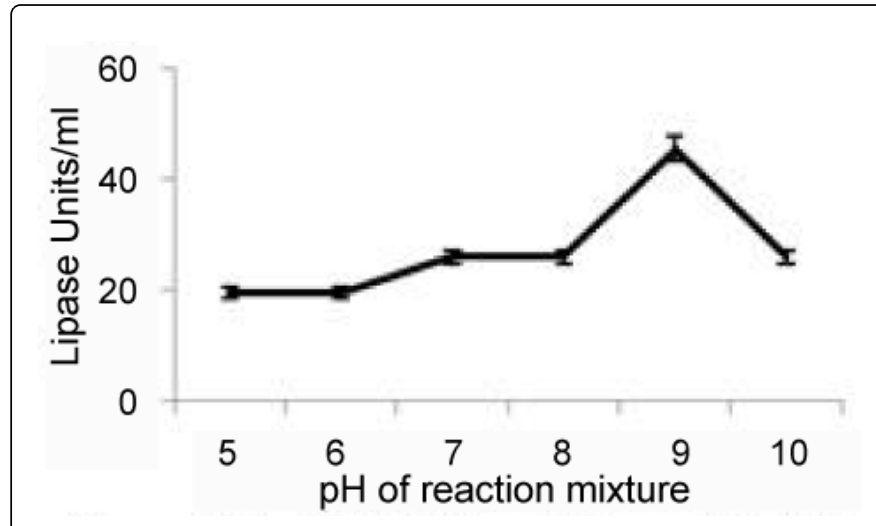

Figure 12: $\mathrm{pH}$ stability of lipase at $30^{\circ} \mathrm{C}$.

\section{Partial purification of lipase}

Partial purification of lipase was carried out using ammonium sulphate precipitation. 5.8 fold purification was obtained with an overall yield of $32.6 \%$ when $80 \%$ of ammonium sulphate concentration was used. Dialysis was carried out to remove the remaining salts to obtain partially purified enzyme.

\section{Determination of molecular weight of lipase}

Partially purified enzyme was treated with SDS-PAGE in order to determine its molecular weight. The figure below shows (a) M represents marker of ACT-IDMW-24, (b) L1 represents lipase which is precipitated by ammonium sulphate at $80 \%$ saturation, (c) L2 represents crude enzyme. The molecular mass of lipase was found to be $45 \mathrm{kDa}$.

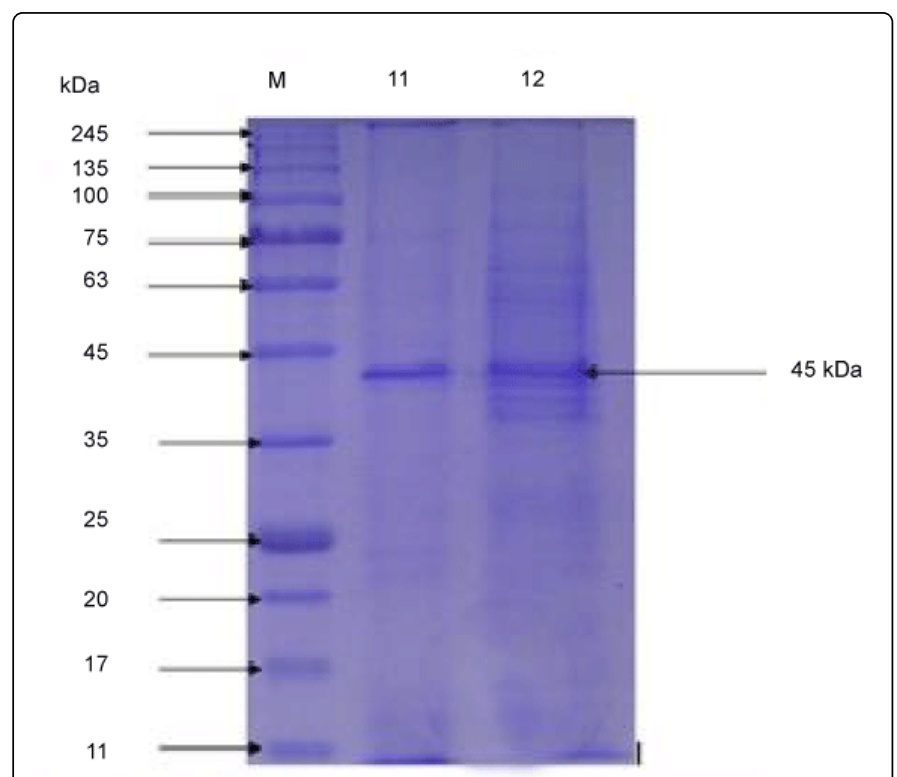

Figure 13: Molecular weight determination of partially purified lipase from P.putida by SDS-PAGE. 


\section{Discussion}

Varying $\mathrm{pH}$ of the growth medium indicated that $P$. putida grows well in an alkaline medium and its growth decreases in strongly alkaline and acidic medium. Somewhat similar results were obtained by Patil and Chaudhri $[1,5]$ who showed that $P$. aeruginosa grew best in $\mathrm{pH}$ range of 8-10.

By changing the incubation temperature of the growth medium, the optimum temperature for lipase production was identified as $30^{\circ} \mathrm{C}$. Increasing or decreasing the temperature causes a decrease in enzyme units showing that $P$. putida is a mesophilic bacterium $30^{\circ} \mathrm{C}$. Similar results have been shown by Padhiar et al. [15] for $P$. aeruginosa and Kiran et al. [16] who found $30^{\circ} \mathrm{C}$ as the optimum temperature for enzyme production from Pseudomonas $s p$.

Increasing the incubation time showed that by 24 hours lipase production had been initiated and at 48 hours the bacterium had obtained logarithmic growth phase. After 48 hours the enzyme units tend to decrease suggesting that enzyme may have been either degraded or become non-functional due to decrease in lipidic substrate or increase in acidity after consumption of medium. Such a trend has also been reported by Chigusa et al. [17] with $P$. aeruginosa EF2 and Kathiravan et al. [18].

When different carbon sources such as carbohydrates and oil cakes were used, results suggests that carbohydrates were not able to stimulate lipase production as oil cakes were able to do so. Maximum enzyme production with mustard oil cake suggests that mustard oil cake is a better inducer for lipase than coconut oil cake and other carbon sources used. Such results have also been reported by Joseph et al. [18] when they used oil cakes as substrates for lipase production. While with carbohydrates Kathiravan et al. [18] found glucose and fructose giving similar results while maltose inhibited lipase production. They are also similar to results by Pogaku et al. [19].

Results using different nitrogen sources show that yeast extract and peptone were better for lipase production than other nitrogen sources. Yeast extract and peptone gave similar results when used by Sirsisha et al. [20], Mobarak-Qamsari et al. [21] and Lau et al. [22].

When different salt conditions were used, the result suggests that high salt concentration tend to inhibit lipase production while low salt concentration does not aid in lipase production. Such results were also obtained by Sangeetha et al. [23] who used salt concentration to obtain high lipase yield.

The optimized medium was found to produce lesser enzyme units than other media used for optimization because of the $\mathrm{pH}$ of the optimized medium that was set at 10 which was found to be better for growth of $P$. putida but not optimal for lipase production. The conditions of $\mathrm{pH}$ may not have been suitable for maximal lipase production. Similar reports were also given by Sekhon et al. [24] who found that good bacterial growth occurred at $\mathrm{pH} 4-11$ whereas lipase production was maximum at $\mathrm{pH} 7$ and decreased above or below this $\mathrm{pH}$.

The results of optimum working temperature for lipase are confirmed by studies done by Gilbert et al. [25] showed that lipase activity decreased after $45^{\circ} \mathrm{C}$ while Zaliha et al. [26] found lipase activity to be optimum above $40^{\circ} \mathrm{C}$. The results for varying optimum $\mathrm{pH}$ coincide with various studies carried out by Mubarak-Qamsari et al. [21] which reveal similar results that the enzyme has the ability to work at $\mathrm{pH} 9$ and 10. Thermostability results are similar to such studies carried out on lipase by Ranjitha et al. [27] where the enzyme was stable at $30^{\circ} \mathrm{C}$ while $\mathrm{pH}$ stability studies also agree with studies carried out by Annamalai et al. [28] who also observed that the lipase from Bacillus licheniformis was stable at $\mathrm{pH} 9$.

The molecular mass of lipase obtained from Pseudomonas putida was determined by utilizing SDS-PAGE. The results revealed that molecular mass of lipase was $45 \mathrm{kDa}$. Less number of bands was observed in partially purified sample compared to the bands of crude enzyme, which proved that lipase partial purification was exceptional. Marker used during procedure was ACT-IDMW-24 (Figure13). Longshaw et al. [29] identified a lipase gene in Staphylococcus epidermidis having molecular size of $45 \mathrm{kDa}$.

\section{Conclusion}

In the present work lipase from Pseudomonas putida has been found to give substantial production of lipase by submerged fermentation using mustard oil cake and yeast extract or peptone in production medium and differs from other lipases that it has a good stability at a wide temperature. It also is significant that it gives good activity in alkaline $\mathrm{pH}$ and high temperature therefore making it suitable to be used as a component in laundry detergents etc.

\section{Acknowledgements}

I would like to thank the head of department; Dr. Ikram ul Haq, for providing all the necessary help to complete my research work, my supervisor Dr. Zahid for helping me through the research and the rest of the teachers of the department. A special thanks to all the coworkers who helped me in the completion of my research work.

\section{References:}

1. Patil KJ, Chopda MZ, Mahajan RT (2011) Review: Lipase Biodiversity Indian.J Sci Technol: 971-982.

2. Saxena RK, Sheoran A, Giri B, Davidson WS (2003) Purification strategies for microbial lipases. J Microbiol Methods 52: 1-18.

3. Tehreema I, Niaz M, Zia MA, Jabeen R, Aftab MN (2011) Biosynthesis of extracellular lipases by Bacillus sp. (MBLB-3) in relation to the nutritional conditions. Pak J Bot: 2587-2591

4. Sharma AK, Tiwari RP, Hoondal GS (2001) Properties of a thermostable and solvent stable extracellular lipase from a Pseudomonas sp. AG-8. J Basic Microbiol 41: 363-366.

5. Kiran GS, Shanmughapriya S, Jayalakshmi J, Selvin J, Gandhimathi R, et al. (2008) Optimization of extracellular psychrophilic alkaline lipase produced by marine Pseudomonas sp. (MSI057). Bioprocess Biosyst Eng 31: 483-492.

6. Aires-Barros MR, Taipa MA, Cabral JMS (1994) Isolation and purification of lipases. In: Wooley P, Peterson SB (Ed) Lipases-their structure, biochemistry and application. Cambridge University Press, Cambridge: 243-270

7. Lotti M, Monticelli S, Montesinos JL, Brocca S, Valero F, et al. (1998) Physiological control on the expression and secretion of Candida rugosa lipase. Chem Phys Lipids 93: 143-148.

8. Rathi P, Goswami VK, Sahai V, Gupta R (2002) Statistical medium optimization and production of a hyperthermostable lipase from Burkholderia cepacia in a bioreactor. J Appl Microbiol 93: 930-936.

9. Ito T, Kikuta H, Nagamori E, Honda H, Ogino H, et al. (2001) Lipase production in two-step fed-batch culture of organic solvent-tolerant Pseudomonas aeruginosa LST-03. J Biosci Bioeng 91: 245-250.

10. Chisti Y (1999) Solid substrate fermentations, enzyme production, food enrichment. In: Flickinger MC, Drew SW (Ed). Encyclopedia of bioprocess technology: fermentation, biocatalysis and bioseparation (vol 5) Wiley New York.: 2446-2462. 
Citation: Fatima H, Khan N, Rehman AU, Hussain Z (2014) Production and Partial Characterization of Lipase from Pseudomonas putida.

11. Reimerdes EH, Franke K, Sell M (2004) Influencing functional properties of egg yolk by using phospholipases, paper presented at Conf on Food Structure and Food Quality, held on 3-7 October 2004

12. Pandey A, Benjamin S, Soccol CR, Nigam P, Krieger N, et al. (1999) The realm of microbial lipases in biotechnology. Biotechnol Appl Biochem $29: 119-131$.

13. Malcata FX (1996) Scope and Strategies. Nato ASI Ser., Ser. E: Engineering of/with Lipases Vol. 317 Kluwer: 1-5.

14. Padhiar J, Das A, Bhattacharya S (2011) Optimization of process parameters influencing the submerged fermentation of extracellular lipases from Pseudomonas aeruginosa, candida albicans and Aspergillus flavus. Pak J Biol Sci 14: 1011-1018.

15. Dub AE, Shareck F, Hurtubise Y, Beauregard M, Daneault C (2008) Enzyme-based approaches for pitch control in thermomechanical pulping of softwood and pitch removal in process water. J Chem Technol Biotechnol 83: 1261-1266

16. Kiran GS, Shanmughapriya S, Jayalakshmi J, Selvin J, Gandhimathi R, et al. (2008) Optimization of extracellular psychrophilic alkaline lipase produced by marine Pseudomonas sp. (MSI057). Bioprocess Biosyst Eng 31: 483-492.

17. Chigusa S, Hasegawa T, Yamamoto N, Watanabe Y (1996) Treatment of wastewater from oil manufacturing plant by yeasts. Wat Sci Technol 34: 51-58

18. Kathiravan T, Marykala $\mathrm{K}$, Sundaramanickam A, Kumaresan $\mathrm{S}$ and Balasubramanian T (2012) Studies on nutritional requirements of Pseudomonas aeruginosa for lipase production. Adv Appl Sci Res: 591-598

19. Pogaku P, Suresh A, Srinivas P, Reddy SR (2010) Optimization of lipase production by Staphylococcus sp. Lp12. Afr J Biotechnol: 882-886

20. Sirisha E, Rajasekar N, Narasu ML (2010) Isolation and Optimization of Lipase Producing Bacteria from Oil Contaminated Soils. Adv Biol Res 4: 249-252
21. Mobarak-Qamsari E, Kasra-Kermanshahi R, Moosavi-Nejad Z (2011) Isolation and identification of a novel, lipase-producing bacterium, Pseudomnas aeruginosa KM110. Iran J Microbiol 3: 92-98.

22. Lau HL, Ariff A, Woo KK, Ling TC, Hii SL (2011) Production and optimization of alkalostable lipase by alkalophilic Burkholderia cenocepacia ST8. Afr J Biotechnol 10: 7002-7009

23. Sangeetha R, Geetha A, Arulpandi I (2008) Optimization of protease and lipase production by Bacillus pumilus SG 2 isolated from an industrial effluent The Internet J Microbiol 5

24. Sekhon A, Dahiya N, Tewari RP, Hondal GS (2006) Production of extracellular lipase by Bacillus megaterium AKG-1 in submerged fermentation Indian J Biotechnol 5: 179-183

25. Gilbert EJ, Cornish A, Jones CW (1991) Purification and properties of extracellular lipase from Pseudomonas aeruginosa EF2. J Gen Microbiol 137: 2223-2229.

26. Rahman RN, Baharum SN, Basri M, Salleh AB (2005) High-yield purification of an organic solvent-tolerant lipase from Pseudomonas sp. strain S5. Anal Biochem 341: 267-274.

27. Ranjitha P, Karthy ES, Mohankumar A (2009) Purification and Characterization of the Lipase from Marine Vibrio fischeri International J Biol 1: 48-55

28. Annamalai N, Elayaraja S, Vijayalakshmi S, Balasubramanian T (2011) Thermostable alkaline tolerant lipase from Bacillus licheniformis using peanut oil cake as a substrate. Afr J Biochem Res 5: 176-181

29. Longshaw CM, Farrell AM, Wright JD, Holland KT (2000) Identification of a second lipase gene, gehD, in Staphylococcus epidermidis: comparison of sequence with those of other staphylococcal lipases. Microbiology 146: 1419-1427. 